\title{
Somatotype and Body Fat Percentages among Malaysian Female Basketball Players 馬來西亞女子籃球選手的體型及身體脂肪
}

\author{
Kim Geok SOH \\ Sports Studies Department, \\ Faculty of Educational Studies, \\ University Putra Malaysia, MALAYSIA \\ 蘇金玉 \\ 馬來西亞布特拉大學敉育學院運動學系
}

\author{
Kim Lam SOH \\ Department of Community Health, \\ Faculty of Medicine and Health Sciences, \\ University Putra Malaysia, MALAYSIA
}

\begin{abstract}
This study sought to determine the somatotype and body fat content of elite Malaysian female basketball players. It also sought to differentiate the somatotype and body fat content by playing position - attack, centre and defence. The somatotype was determined using the Heath Carter Somatotyping method and the body fat content by the skinfold method. Twelve elite female basketball players who represented Malaysia in the 1997 SEA Games were selected as the subjects (mean age of $22.75 \pm 2.67$ years). It was found that the players were predominantly meso-endomorphic with a mean somatotype of 4.49 $\pm 1.20-3.45 \pm 0.77-2.91 \pm 0.89$. The centre and defence players had meso-endomorphic bodies, but the attack players endomosomorphic bodies. The mean body fat content was $19.68 \% \pm 4.93$. The defence were the fattest, followed by the centre and attack players. Female American basketball players have a body fat content of 10 to $16 \%$ while the Malaysian players in this study $10 \%$ to $26 \%$.
\end{abstract}

Keywords : Somatotype, body fat percentage, basketball players, playing position

\section{摘 要}

本文旨在探討馬來西亞女子籃球選手的體型及體脂比例，並分析球員的位置,結果顯示：防守球員偏向接近肌肉型,脂肪比例平均 為 19.68\% 4.93,對比美國籃球員而言，馬來西亞選手的體脂較高.

\section{Introduction}

Basketball is a very popular contact game in Malaysia, especially with the Chinese community. It was introduced to Malaya (as West Malaysia then was) as early as 1920 but there has not been much research on the physical and physiological attributes of the players (Malaysian Amateur Basketball Association, 1995). Research in the United States and Canada, however, has shown the meso-endomorphic somatotype to be most suitable body for female players
(Alexander, 1976; Vaccaro, Clarke, \& Wrenn, 1979). In addition, a body fat content of $10-16 \%$ was found to be ideal (Wilmore $\&$ Costill, 1994). As the body size, shape and composition play important roles in determining the success of an athlete (Wilmore \& Costill, 1994), this study was undertaken to determine the bodily characteristics (somatotype and body fat) of Malaysian female basketball players by their playing positions (attack, centre and defense), and to compare the results with other players in other countries. 


\section{Methods and Procedures}

\section{Subjects}

The subjects in this study were elite Malaysian female basketball players $(\mathrm{N}=12)$, all of who represented the country in the 1997 SEA Games, Jakarta, Indonesia. Their mean age was $22.75 \pm 2.67$ years, mean height $171.71 \pm 5.45 \mathrm{~cm}$ and mean body weight $63.88 \pm 6.46 \mathrm{~kg}$. They have had at least nine years experience playing basketball at inter-state level and above.

\section{Procedure and Instrumentation}

The study was carried out in Malaysian National Sports Institute, Bukit Jalil. A trained physiologist from the institute took the measurements. According to Tothill and Stewart (2002), measurements taken by trained personnel should be fairly reliable. The instruments used were Harpenden calipers, Spreading calipers, measuring tape, ruler, SOEHNLE weighing scale and black marker. The somatotype test was done using the Heath and Carter Somatotyping method (Fox, Bowers, \& Foss, 1993). The measurements taken were height, body mass, skinfold thickness over the triceps and calf, biceps and calf girths, and humerus and femur widths.

The body fat content was determined by skinfold measurement, which results are highly correlated $(r=0.85)$ with those from Hydrostatic Weighing (Pollock, Schmidt, \& Jackson, 1980; Adams, 1994). The calculation of body fat content was based on the formula of Pollock et al. (1980). Seven locations were pinched - chest, midaxilla, subscapular, triceps, suprailiac, navel and thigh - as the more locations taken the more accurate the results (Johnson \& Nelson, 1986). All the procedures used for the somatotype and body fat content were from the Anthropometric standard reference manual (Lohman, Roche, \& Martorell, 1991).

The measurements were taken starting on the right side of the body, slowly rotating around to avoid placing excessive pressure on any spot by the pinching of the instruments. Two readings were first taken for each skinfold/muscle/bone, rounded up to the nearest $\mathrm{mm}$ or $\mathrm{cm}$. Only if the two readings were within one $\mathrm{mm}$ or $\mathrm{cm}$ of each other were they accepted. If not, a third measurement was taken and the two closest (subject to them being within the error range) accepted.

\section{Statistical Analysis}

The somatotype was described using the Heath Carter Somatotyping method. The rating for the endomorphymesomorphy-ectomorphy component was used to determine the overall body type. The body fat content was reported in percent of the body weight.

\section{Resullts}

The body type of the players was, on average, mesoendomorphic with a mean value of $4.49 \pm 1.20-3.45 \pm 0.77$

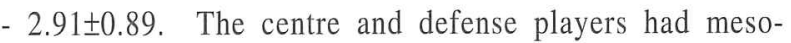
endomorphic bodies with somatotype values of $4.79 \pm 1.16$ $3.25 \pm 0.85-3.01 \pm 0.79$ and $5.52 \pm 0.05-3.87 \pm 0.28-2.03 \pm$ 0.79 , respectively. However, the attack players were endomosomorphic with a somatotype value of $3.53 \pm 02.98-3.54 \pm$ $0.84-3.20 \pm 1.01$. The overall body fat content was $19.68 \pm 4.93 \%$, with a range of $10.40 \%$ to $26.20 \%$. The defense players were the fattest $(23.00 \pm 3.39)$, followed by the centre $(21.62 \pm 3.91)$ and attack $(15.10 \pm 4.12 \%)$ players (see Table 1).

Table 1. Somatotype and Body Fat Result according to Playing Position.

\begin{tabular}{|c|c|c|c|c|}
\hline Playing & Position & Somatotype & & Body Fat (\%) \\
\hline \multicolumn{5}{|c|}{ Endomorphhy Mesomorphy Ectomorphy } \\
\hline Defender & $5.52 \pm 0.05$ & $3.87 \pm 0.28$ & $2.03 \pm 0.79$ & $23.00 \pm 3.39$ \\
\hline Centre & $4.79 \pm 1.16$ & $3.25 \pm 0.85$ & $3.01 \pm 0.79$ & $21.62 \pm 3.91$ \\
\hline Attacker & $3.53 \pm 0.98$ & $3.54 \pm 0.84$ & $3.20 \pm 1.01$ & $15.10 \pm 4.12$ \\
\hline Overall & $4.49 \pm 1.20$ & $3.45 \pm 0.77$ & $2.91 \pm 0.89$ & $19.68 \pm 4.93$ \\
\hline \multicolumn{5}{|l|}{ Mean } \\
\hline
\end{tabular}

\section{Discussion}

The Malaysian basketball players generally had a meso-endomorphic somatotype. This is in line with Alexander (1976) and Vaccaro et al. (1979) who found that female basketball players in the United States and Canada had the same somatotype. A meso-endomorphic body is the ideal for female basketball players because it is tougher and more stable. This is needed in basketball which involves a lot of body contact and rapid darting about. Nevertheless, in comparing the endomorphic and mesomorphic components of the subjects in this study with those found by Alexander (1976) and Vaccaro et al. (1979), the Malaysian players were more endomorphic (fatter) and less mesomorphic (muscular). As movement is easier with more mesomorphy, the US and Canadian players have, therefore, a better somatotype than the Malaysian players. 
The Malaysian body fat content of $19.86 \%$ was above the ideal for elite female basketball players of $10-16 \%$ as stated by Wilmore and Costill (1994). They felt that body fat in excess of $25 \%$ would limit the players' movements and tire them faster from having to lug the extra weight around. Moreover, more oxygen would be needed to catabolise the fat for the extra energy required (Fox et al., 1989). All these would lower the playing performance and prevent the players from playing to their full potential (Telford, Barnes, Tumilty, \& Hahn, 1985).

\section{Conclusions}

Malaysian female basketball players had the same somatotype as female basketball players from other countries. Nevertheless, although they had the same meso-endomorphy, the Malaysian players had higher endomorphy and lower mesomorphy, i.e., they were fatter and less muscular. The attack players had the most suitable somatotype and body fat with an endo-mesomorphic somatotype and body fat content of $15.10 \%$.

\section{Acknowledgements}

The author wishes to thank the Malaysian Basketball Association (MABA) for their support in this study. Gratitude is also expressed to the basketball coach, Mr. Tan SW, and the subjects who participated in this study. Finally, a special 'thank you' to the Malaysian National Sports Institute staff who gave their technical and material support.

\section{References}

Adam, K., O'Shea, K. L., \& Climstein, M. (1992). The Effect of Six Weeks of Squat, Plyometric and Squatplyometric Training on Power Production. Journal of Sport Science Research. 6 (1), 36-41.

Alexander, M. J. L. (1976). The Relationship of Somatotype and Selected Anthropometric Measures to Basketball Performance in Highly Skilled Females. The Research Quarterly for Exercise and Sport. 47(4): 575-585.

Fox, E. L., Bowers, R. W., \& Foss, M. L (1993). The Physiological Basis for Exercise and Sport (5th Ed.). Dubuque : Brown and Benchmark.

Fox, E. L., Bowers, R. W., \& Foss, M. L. (1989). The Physiological Basis of Athletics (4th Ed.). Dubuque : Wm. C. Brown Publishers.
Johnson, B. L., \& Nelson, J. K (1986). Practical Measurement for Evaluation in Physical Education (4th Ed.). Edina : Burgess Publishing.

Lohman, T. G., Roche, A. F., \& Martorell, R. (1991). Anthropometric Standardization Reference Manual (Abridged Ed.). Champaign : Human Kinetics Books.

Malaysian Basketball Association (1995). Sejarah Persatuan Bola Keranjang Malaysia(The history of Malaysian Basketball Association). Kuala Lumpur: MABA Publisher.

Pollock, M. L., Schmidt, H. D., \& Jackson, A. S. (1980). Measurement of Cardiorespiratory Fitness and Body Composition in The Clinical Setting. Comprehensive Therapy. 6 (9), 12-27.

Tothill, P., \& Stewart, A. (2002). Estimation of Thigh Muscle and Adipose Tissue Volume using Magnetic Resonance Imaging and Anthropometry. Journal of Sport Sciences. 20 (7), 563-576.

Telford, R., Barnes, J., Tumilty, D., \& Hahn, A. (1985). Body Fat Measures in Athletes With A Special Reference to Female Basketballers and Netballers. Sports Coach. 9 (1), 32-37.

Vaccaro, P., Clarke, D. H., \& Wrenn, J. P. (1979). Physiological Profiles of Elite Women Basketball Players. The Journal of Sports Medicine and Physical Fitness. 19, 45-52.

Wilmore, J. H., \& Costill, D. L. (1994). Physiology of Sports and Exercise. Champaign : Human Kinetics Publisher.

\section{Correspondence:}

Author: Soh Kim Geok and Soh Kim Lam

Dr. Soh Kim Geok

Sports Studies Department,

Faculty of Educational Studies,

University Putra Malaysia, MALAYSIA.

\section{Soh Kim Lam}

Department of Community Health, Faculty of Medicine and Health Sciences, University Putra Malaysia, MALAYSIA.

E-mail:kim@educ.upm.edu.my or kimgeoks@yahoo.com Tel:603-89468153 (Office) or 6019-3649715 (Mobile) Fax::603-89435386 